\title{
Associations between initial injury severity in acute hand, wrist or forearm injuries and disability ratings and time to return to work
}

\author{
Sercan Çapkın, M.D., ๑ Ali Cavit, M.D., \ Kutay Yılmaz, M.D., \\ (1) Eralp Erdoğan, M.D., 구 Tufan Kaleli, M.D.
}

Department of Orthopaedics and Traumatology, Division of Hand Surgery, Uludağ University Faculty of Medicine, Bursa-Turkey

\begin{abstract}
BACKGROUND: This study aimed to examine the relationships between the initial anatomic severity of hand, wrist and forearm injuries, as evaluated by the Modified Hand Injury Severity Score (MHISS), and each of the following parameters: disability rating and time to return to work.
\end{abstract}

METHODS: In this study, 94 patients who underwent operations due to acute hand, wrist and forearm injuries were included. MHISS was used to assess the severity of the injury. Disability rates of the patients were calculated six months after injury in accordance with the 'Regulation on Disability Criteria, Classification and Health Board Reports to be Given to Disabled People'. The time to return to work was defined as the length of time (in days) between the injury and the patient's return to work. Spearman rank correlation analysis was performed to analyse correlations between the MHISS and each of the following: disability rates and time to return to work.

RESULTS: The mean overall MHISS was 125.23 (5-880). The mean overall upper extremity disability ratio (UEDR) was I7.64 \pm 22.6

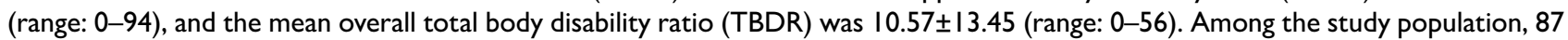
(92.6\%) patients were able to return to their jobs. The mean overall time to return to work was I38.69 (range: 35-365 days). A statistically significant correlation was found between MHISS and UEDR, TBDR and time to return to work and UEDR, TBDR ( $<<0.00 \mathrm{I})$.

CONCLUSION: As a result, as the initial injury severity increased, greater disability remained and the time to return to work increased. Predicting prognosis by determining the injury severity in the initial evaluation of patients may be important in predicting a patient's future permanent disability level, which can contribute to maintaining patient expectations at a reasonable level, thereby aiding in psychosocial support.

Keywords: Disability ratings; MHISS; severity of injury; time to return to work.

\section{INTRODUCTION}

Hand injuries constitute a substantial proportion of all injuries. They may cause long-term physical and functional disabilities, as well as a serious economic effect on employmen. [1,2] The Hand Injury Severity Score (HISS) was developed by Campbell and Kay to investigate the extent of injuries and likely outcomes. ${ }^{[3]}$ The Modified Hand Injury Severity Score (MHISS) was developed later since the original HISS is specific for hand injuries distal to the carpal bones. The MHISS includes injuries both distal and proximal to the carpal bones up to the elbow level. ${ }^{[4]}$

After the injury, it is important to determine the patient's recovery time, when the patient can return to work, and whether there is a permanent disability. The HISS and MHISS have been used in various studies to assess various consequences of a hand injury, such as injury pattern, functional outcome, when the patient can return to work, workers' compensation in industrial injuries, injury-related economic

Cite this article as: Çapkın S, Cavit A, Yılmaz K, Erdoğan E, Kaleli T. Associations between initial injury severity in acute hand, wrist or forearm injuries and disability ratings and time to return to work. Ulus Travma Acil Cerrahi Derg 2020;26:453-461.

Address for correspondence: Sercan Çapkın, M.D.

Uludağ Üniversitesi Tıp Fakültesi, Ortopedi ve Travmatoloji Anabilim Dalı, El Cerrahisi Bilim Dalı, 16059 Bursa, Turkey

Tel: +90 224 - 2950000 E-mail: sercancapkn@gmail.com

Ulus Travma Acil Cerrahi Derg 2020;26(3):453-46I DOI: 10.14744/tjtes.2019.40524 Submitted: 12.02.2019 Accepted: 06.08.2019 Online: I3.05.2020

Copyright 2020 Turkish Association of Trauma and Emergency Surgery 
costs and whether there is permanent disability. ${ }^{[3-14]}$ In most studies, the HISS has been correlated with time to return to work, functional outcome and healing time. A previous study showed a statistically significant correlation between the HISS score and the American Medical Association (AMA) impairment rating, evaluated by loss of active movement. ${ }^{[2]}$ In Turkey, patients' disability ratings are determined as percentages (\%) based on the 'Regulation on Disability Criteria, Classification and Health Board Reports to be Given to Disabled People'. ${ }^{[15]}$ To our knowledge, the relationship between MHISS and disability ratings has not been evaluated in a population of patients in Turkey.

This study aimed to examine the relationships between the initial anatomic severity of hand, wrist and forearm injuries, as evaluated by the MHISS, and each of the following parameters: disability rating and time to return to work.

\section{MATERIALS AND METHODS}

This retrospective study was approved by the Clinical Research Ethics Committee of the Bursa Uludağ University Faculty of Medicine (Approval no: 2019-2/9). Between August 2017 and October 2018, 94 patients who underwent operations in our hospital due to acute hand, wrist and forearm injuries were included in this study. The inclusion criteria for this study were as follows: patients were 18 to 65 years of age at the time of injury; patients were employed full-time before the injury; at least six months passed since their injuries and all patients were clinically stable, no longer requiring splinting devices. The exclusion criteria for this study were any of the following: patients had injuries proximal to the forearm; patients had bilateral injuries; patients had concomitant injuries other than hand injury; patients had a previous history of severe hand and forearm injuries and patients' records had insufficient detail regarding the injury.

The patients' demographic characteristics were recorded, including their age, sex, injured side and dominant side. Each injury's aetiology was classified into one of six categories: work accidents, traffic accidents, home accidents, gunshot injuries, assault and self-inflicted injuries. The pre-injury occupational category, which depended on the physical characteristics of the job, were categorised into two major groups: white-collar and blue-collar workers. Blue-collar jobs were defined as hard manual labour, whereas white-collar jobs were defined as office work. Furthermore, blue-collar workers were classified into four subcategories: construction workers, textile workers, mechanic/repair worker and others. Injury data were collected from patient records, including photographs of the injury in the operating room, notes of the intraoperative findings and radiographs of the injury. The MHISS was calculated using these data. In the MHISS, integument, skeletal, motor (tendons and muscles) and neurovascular structures were assessed and graded individually. Furthermore, each injured structure was rated in an absolute and weighted manner. The overall MHISS comprised the total of the scores for integument, skeletal, motor and neurovascular components. The MHISS was grouped into four grades: minor $(\leq 20)$, moderate $(2 I-50)$, severe $(5 I-\mid 00)$ and major $(\geq \mid 0 I)$.

Patient outcomes were evaluated by calculating disability rates after six months of injury. The upper extremity and total body disability ratio of patients were calculated in accordance with the 'Regulation on Disability Criteria, Classification and Health Board Reports to be Given to Disabled People'. ${ }^{[15]}$ The disability ratio was calculated by an experienced orthopaedic surgeon who had previously served on the Health Board.

\section{Measurement of Disability Ratings}

The following evaluation procedures were used to assess injured patients' disability ratings when they reached final stable conditions:

I. To calculate the disability rate for any finger, all pathologies in the finger (e.g., amputation, loss of sensation and limitation of movement) were combined. The Balthazard formula was used to combine two or more degrees of disability. ${ }^{[15]}$

2. Disability values for each individual finger were combined, and the percentage of total hand disability was calculated.

3. The percentage of hand disability was then converted to upper extremity disability using a standard conversion table provided within the regulation.

4. Finally, the percentage of upper extremity disability was converted to total body disability using a standard conversion table provided in the regulation.

Before the injury, all the patients were employed full-time. The patients' times to return to work were noted in post-injury records. The time to return to work was defined as the length of time (in days) between the injury and the patient's return to work.

Statistical analysis was performed using SPSS version 20.0 (SPSS Inc., Chicago, IL, USA). Descriptive statistics recorded were mean, standard deviation, minimum/maximum values and percentage. Non-parametric data analyses were performed using the Kruskal-Wallis and Mann-Whitney $U$ tests. Spearman rank correlation analysis was performed to analyse correlations between the MHISS and each of the following: disability rates and time to return to work. All tests were two-sided, and p-values of less than 0.05 were considered statistically significant. The most important results are shown in the accompanying tables and figures.

\section{RESULTS}

Based on our inclusion criteria, 94 patients were included in this study, all of whom had undergone operations at our 
clinic due to hand, wrist or forearm trauma. Among these 94 patients, 23 (24.5\%) were female and 71 (75.5\%) were male. The patients' mean age was 38.2I \pm 12.95 (range: 18-64) years. There were $46(48.9 \%)$ patients with a right-sided injury and 48 (5I.1\%) with a left-sided injury. Dominant-side injuries were present in $49(52.1 \%)$ patients, while non-dominant-side injuries were present in 45 (47.9\%) patients. The aetiologies of the injuries were work accidents in 49 (52.1\%) patients, traffic accidents in 12 (12.8\%) patients, home accidents in II (1 I.7\%) patients, gunshot injuries in four $(4.3 \%)$ patients, assaults in six (6.4\%) patients and self-inflicted injuries in $12(12.8 \%)$ patients. Anatomically, there were three injured regions: the hand was injured in 50 (53.19\%) patients, the wrist was injured in 18 (19.14\%) patients and the forearm was injured in eight $(8.51 \%)$ patients, and the remaining patients had combined hand, wrist and forearm injuries [hand and wrist in seven (7.44\%) patients; wrist and forearm in five $(5.31 \%)$ patients and hand, wrist and forearm in six (6.38\%) patients]. According to the pre-injury occupational category, $45(47.9 \%)$ of the patients were white-collar workers, whereas $49(52.1 \%)$ patients were blue-collar workers [10 (10.6\%) were construction workers, 17 (18.1\%) patients were textile workers, I3 (I3.8\%) patients were mechanic/ repair workers and $9(9.6 \%)$ patients were other workers].

The mean overall MHISS was 125.23 (5-880). Based on the MHISS values, four injury grades were present: grade I (minor) included $28(29.8 \%)$ patients with a mean MHISS of 14.39 \pm 5.74 ; grade 2 (moderate) included 19 (20.2\%) patients with a mean MHISS of 38.89 \pm 7.55 ; grade 3 (severe) included $22(23.4 \%)$ patients with a mean MHISS of $73.05 \pm 15.78$ and grade 4 (major) included $25(26.6 \%)$ patients with a mean MHISS of $360.92 \pm 273.83$.

The distributions of the patients, according to grades of MHISS for demographic variables (e.g., sex, injured side and dominant/non-dominant-sided injuries), are shown in Tables I-3. Minor injuries were more common in women; major injuries were more common in men $(p<0.01)$. There were no significant relationships between MHISS grade and injured side or dominant/non-dominant-sided injuries $(p>0.05)$.

The patient distribution and mean MHISS values according to the aetiology of injuries are shown in Table 4. The difference

Table I. Sex distribution of the patients according to grade of MHISS

\begin{tabular}{|c|c|c|c|c|c|c|c|c|c|c|}
\hline \multirow[t]{2}{*}{ Sex } & \multicolumn{2}{|c|}{ Minor } & \multicolumn{2}{|c|}{ Moderate } & \multicolumn{2}{|c|}{ Severe } & \multicolumn{2}{|c|}{ Major } & \multicolumn{2}{|c|}{ Total } \\
\hline & $\mathbf{n}$ & $\%$ & $n$ & $\%$ & $\mathbf{n}$ & $\%$ & $\mathbf{n}$ & $\%$ & $\mathbf{n}$ & $\%$ \\
\hline Female & 10 & 43.5 & 9 & 39.1 & 2 & 8.7 & 2 & 8.7 & 23 & 24.5 \\
\hline Male & 18 & 25.4 & 10 & 14.1 & 20 & 28.2 & 23 & 32.4 & 71 & 75.5 \\
\hline
\end{tabular}

$\left(\chi^{2}:\right.$ 13.8; $\left.p<0.01\right)$. MHISS: Modified Hand Injury Severity Score.

Table 2. Injured side distribution of the patients according to grade of MHISS

\begin{tabular}{|c|c|c|c|c|c|c|c|c|c|c|}
\hline \multirow[t]{2}{*}{ Side } & \multicolumn{2}{|c|}{ Minor } & \multicolumn{2}{|c|}{ Moderate } & \multicolumn{2}{|c|}{ Severe } & \multicolumn{2}{|c|}{ Major } & \multicolumn{2}{|c|}{ Total } \\
\hline & $\mathbf{n}$ & $\%$ & $n$ & $\%$ & $\mathbf{n}$ & $\%$ & $\mathbf{n}$ & $\%$ & $n$ & $\%$ \\
\hline Right & 13 & 28.3 & 6 & 13 & 13 & 28.3 & 14 & 30.4 & 46 & 48.9 \\
\hline Left & 15 & 31.3 & 13 & 27.1 & 9 & 18.8 & 11 & 22.9 & 48 & 51.1 \\
\hline
\end{tabular}

$\left(\chi^{2}: 3.8 ; p>0.05\right)$. MHISS: Modified Hand Injury Severity Score.

Table 3. Dominant/non-dominant side distribution of the patients according to grade of MHISS

\begin{tabular}{|c|c|c|c|c|c|c|c|c|c|c|}
\hline \multirow{2}{*}{$\begin{array}{l}\text { Dominant } \\
\text { hand affected }\end{array}$} & \multicolumn{2}{|c|}{ Minor } & \multicolumn{2}{|c|}{ Moderate } & \multicolumn{2}{|c|}{ Severe } & \multicolumn{2}{|c|}{ Major } & \multicolumn{2}{|c|}{ Total } \\
\hline & $\mathbf{n}$ & $\%$ & $\mathbf{n}$ & $\%$ & $\mathbf{n}$ & $\%$ & $\mathbf{n}$ & $\%$ & $\mathbf{n}$ & $\%$ \\
\hline Yes & 15 & 33.3 & 12 & 26.7 & 7 & 15.6 & 11 & 24.4 & 49 & 52.1 \\
\hline No & 13 & 26.5 & 7 & 14.3 & 15 & 30.6 & 14 & 28.6 & 45 & 47.9 \\
\hline
\end{tabular}

$\left(\chi^{2}: 4.6 ; p>0.05\right)$. MHISS: Modified Hand Injury Severity Score. 
Table 4. Patient distribution, mean MHISS values and disability ratings according to the aetiology of injuries

\begin{tabular}{lccccc}
\hline Aetiology of injuries & $\mathbf{n}$ & $\%$ & MHISS \pm SD & UEDR\% \pm SD & TBDR\% \pm SD \\
\hline Work accident & 49 & 52.1 & $181.04 \pm 258.342$ & $24.41 \pm 28.29$ & $14.59 \pm 16.829$ \\
Traffic accident & 12 & 12.8 & $53 \pm 70.378$ & $8.92 \pm 10.049$ & $5.42 \pm 6.097$ \\
Home accident & 11 & 11.7 & $20.55 \pm 12.16$ & $3.45 \pm 2.697$ & $2.09 \pm 1.446$ \\
Gunshot injury & 4 & 4.3 & $133 \pm 42.755$ & $22.75 \pm 6.292$ & $13.75 \pm 3.594$ \\
Assault & 6 & 6.4 & $61.83 \pm 72.35$ & $11.17 \pm 12.416$ & $6.83 \pm 7.574$ \\
Self inflicting injury & 12 & 12.8 & $94.67 \pm 84.506$ & $13.25 \pm 9.845$ & $7.92 \pm 5.775$ \\
Total & 94 & 100 & $125.23 \pm 200.566$ & $17.64 \pm 22.603$ & $10.57 \pm 13.451$
\end{tabular}

MHISS: Modified Hand Injury Severity Score; UEDR: Upper extremity disability ratio; TBDR: Total body disability ratio; SD: Standard deviation.

Table 5. Patient distribution, mean MHISS values and disability ratings according to pre-injury occupational category

\begin{tabular}{|c|c|c|c|c|c|}
\hline Pre-injury occupational category & $\mathbf{n}$ & $\%$ & MHISS $\pm S D$ & UEDR $\% \pm S D$ & TBDR\% $\%$ SD \\
\hline White collar workers & 45 & 47.9 & $36.78 \pm 45.418$ & $6.7 I \pm 7.2$ & $4.11 \pm 4.318$ \\
\hline Blue collar workers & 49 & 52.1 & $206.47 \pm 248.95$ & $27.67 \pm 26.974$ & $16.51 \pm 16.073$ \\
\hline Construction workers & 10 & 10.6 & $428.4 \pm 302.972$ & $50.3 \pm 32.239$ & $30 \pm 19.195$ \\
\hline Textile workers & 17 & 18.1 & $175.53 \pm 223.967$ & $24.76 \pm 25.791$ & $14.82 \pm 15.323$ \\
\hline Mechanic/repair workers & 13 & 13.8 & $176.69 \pm 229.425$ & $24.54 \pm 24.48$ & $14.69 \pm 14.585$ \\
\hline Others & 9 & 9.6 & $61.33 \pm 24$ & $12.56 \pm 6.002$ & $7.33 \pm 3.64$ \\
\hline Total & 94 & 100 & $125.23 \pm 200.566$ & $17.64 \pm 22.603$ & $|0.57 \pm| 3.45 \mid$ \\
\hline
\end{tabular}

MHISS: Modified Hand Injury Severity Score; UEDR: Upper extremity disability ratio; TBDR: Total body disability ratio; SD: Standard deviation.

between the aetiology of injuries and the mean MHISS values was found to be statistically significant $\left(\chi^{2}: 21.46, p=0.001\right)$. The mean MHISS value was higher in work accidents than in traffic and home accidents, and the differences were statistically significant ( $p$-values were 0.017 and 0.000 , respectively). The mean MHISS value was higher in gunshot injuries than in traffic and home accidents, and the differences were statistically significant ( $p$-values were 0.02 and 0.004 , respectively). The mean MHISS value was higher in self-inflicting injury than in home accidents, and the difference was statistically significant $(p=0.019)$.

The patient distribution and mean MHISS values according to the pre-injury occupational category are shown in Table 5. The difference between the pre-injury occupational category and the mean MHISS values was found to be statistically significant. The mean MHISS value was higher in blue-collar workers than in white-collar workers, and the difference was statistically significant $\left(\chi^{2}: 45.937, \mathrm{p}<0.00 \mathrm{I}\right)$. The mean MHISS value was higher in construction workers than in other bluecollar workers (textile, mechanic/repair and others), and the differences were statistically significant ( $p$-values were 0.006 , 0.007 and 0.001 , respectively).

The mean overall upper extremity disability ratio (UEDR) was 17.64 \pm 22.6 (range: 0-94), and the mean overall total body disability ratio (TBDR) was $10.57 \pm 13.45$ (range: 0-56). Based on MHISS categories, UEDR and TBDR means were statistically different $(p<0.00 I)$. Table 6 shows the disability rating after subdivision into different MHISS categories.

The patient distribution and disability ratings, according to the aetiology of injuries, are shown in Table 4. The difference between the aetiology of injuries and the mean UEDR and TBDR values were found to be statistically significant $(p<0.01)$. The mean UEDR and TBDR values were higher in work accidents than in traffic and home accidents, and the differences were statistically significant $(p<0.05)$. The mean UEDR and TBDR values were higher in gunshot injuries than in traffic and home accidents, and the differences were statistically significant $(p<0.05)$. The mean UEDR and TBDR values were lower in home accidents than in assault and self-inflicting injuries, and the differences were statistically significant $(p<0.05)$.

The patient distribution and disability ratings, according to the pre-injury occupational category, are shown in Table 5 . The difference between the pre-injury occupational categories and the mean UEDR and TBDR values were found to be statistically significant $(p<0.01)$. The mean UEDR and TBDR values were higher in blue-collar workers than in white-collar workers, and the differences were statistically significant 
Table 6. Disability ratings and time to return to work according to grade of MHISS

\begin{tabular}{lccc}
\hline MHISS & UEDR \% (range) & TBDR \% (range) & Time to return to work (days) \\
\hline Minor & $3.14(0-8)$ & $2(0-5)$ & $47.25(35-62)$ \\
Moderate & $7.68(2-13)$ & $4.58(1-8)$ & $107.58(72-150)$ \\
Severe & $13.32(2-22)$ & $8(1-13)$ & $177.27(120-256)$ \\
Major & $45.24(18-94)$ & $27(11-56)$ & $266.61(180-365)$ \\
Total & $17.64(0-94)$ & $10.57(0-56)$ & $138.69(35-365)$ \\
Kruskal-Wallis test & $\mathrm{P}<0.001$ & $\mathrm{P}<0.001$ & $\mathrm{P}<0.001$ \\
\hline
\end{tabular}

MHISS: Modified Hand Injury Severity Score; UEDR: Upper extremity disability ratio; TBDR: Total body disability ratio.

Table 7 . Statistical relationships between variables

\begin{tabular}{lccccc}
\hline Spearman rank order method (correlation coefficient) & MHISS & UEDR & TBDR & Time to return to work & Age \\
\hline MHISS & 1.000 & $0.942^{*}$ & $0.936^{*}$ & $0.981^{*}$ & $0.908^{*}$ \\
UEDR & $0.942^{*}$ & 1.000 & $0.999^{*}$ & -0.059 \\
TBDR & $0.936^{*}$ & $0.999^{*}$ & 1.000 & -0.060 \\
Time to return to work & $0.981^{*}$ & $0.908^{*}$ & $0.900^{*}$ & 1.000 & 0.021 \\
Age & 000 & -0.059 & -0.060 & 87 & 1.000 \\
N & 94 & 94 & 94 & 94 \\
\hline
\end{tabular}

"Correlation is significant at the 0.0 I level (2-tailed). MHISS: Modified Hand Injury Severity Score; UEDR: Upper extremity disability ratio; TBDR: Total body disability ratio.

$(p<0.01)$. The mean UEDR and TBDR values were higher in construction workers than in other blue-collar workers (textile, mechanic/repair and others), and the difference was statistically significant $(p<0.05)$.

Among the study population, 81 (86.2\%) patients were able to return to their jobs without any job modification, whereas six $(6.4 \%)$ returned to work at the same company with a job change. Seven (7.4\%) patients who were not able to return to work were injured after an occupational accident and belonged to the group of blue-collar workers before the injury, of which four were construction workers, two were textile workers and one was a mechanic/repair worker. The time to return to work was noted, except for seven (7.4\%) patients who did not return to their previous place of employment. These patients exhibited MHISS grade 4 (major injury), with a mean MHISS of 738 207.13 (range: 420-880), mean UEDR of $85.14 \pm 15.99$ (range: 54-94) and mean TBDR of $50.71 \pm 9.56$ (range: $32-56$ ). The time to return to work for each MHISS grade of injury is shown in Table 6. Based on MHISS categories, the average times to return to work were statistically different $(\mathrm{p}<0.00 \mathrm{I})$. The average time to return to work was longer in blue-collar workers than in whitecollar workers, and the difference was statistically significant $(p<0.001)$.

Table 7 shows the statistical relationships between variables. We found significant relationships between the MHISS and
UEDR, MHISS and TBDR and MHISS and time to return to work. The Spearman rank-order method showed a correlation coefficient of 0.942 between the MHISS and UEDR (Fig. I); this was statistically significant $(p<0.00 I)$. The Spearman rank-order method showed a correlation coefficient of 0.936 between the MHISS and TBDR (Fig. 2); this was statistically significant $(p<0.00 I)$. The Spearman rank-order method

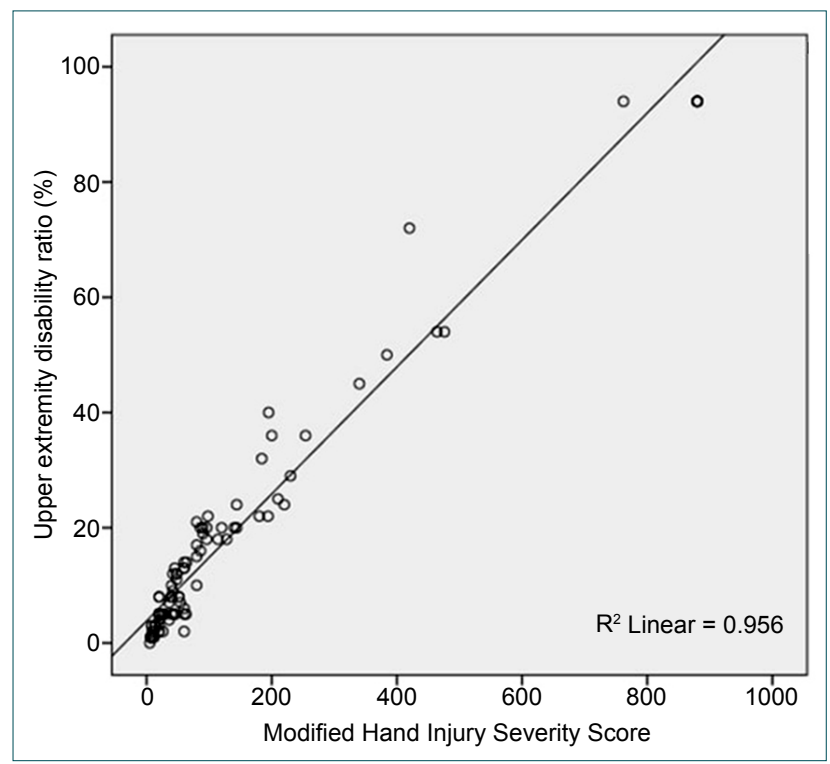

Figure 1. Relationship between Modified Hand Injury Severity Score and upper extremity disability ratio. 
showed a correlation coefficient of $0.98 \mathrm{I}$ between the MHISS and time to return to work (Fig. 3); this was statistically significant $(p<0.00 I)$. We found highly significant relationships between the UEDR and time to return to work, as well as the TBDR and time to return to work. The Spearman rank-order method showed a correlation coefficient of 0.908 between the UEDR and time to return to work; this was statistically significant $(\mathrm{p}<0.00 \mathrm{I})$. The Spearman rank-order method showed a correlation coefficient of 0.9 between the TBDR and time to return to work; this was statistically significant $(p<0.00 \mathrm{I})$. There were no significant relationships between age and the following variables: MHISS, UEDR, TBDR and time to return to work.

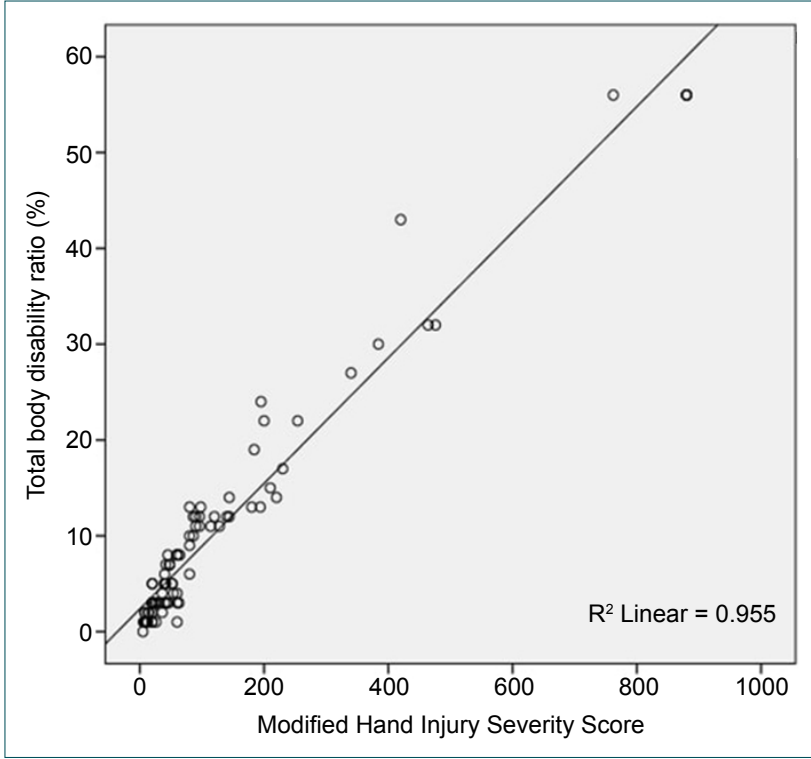

Figure 2. Relationship between Modified Hand Injury Severity Score and total body disability ratio.

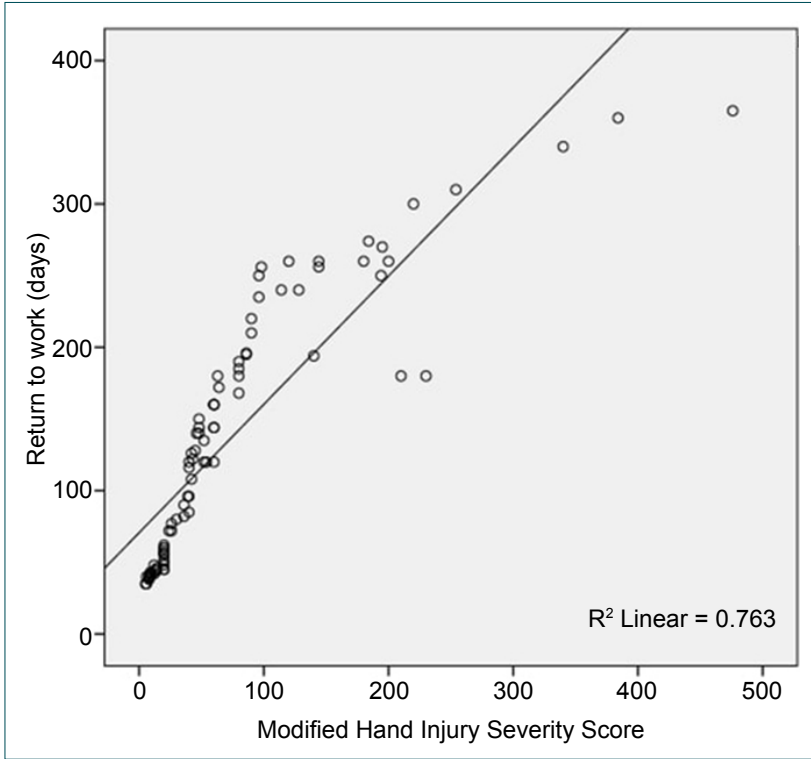

Figure 3. Relationship between Modified Hand Injury Severity Score and time to return to work.

\section{DISCUSSION}

Scoring systems have been used in trauma surgery for more than 40 years. ${ }^{[16]}$ Campbell and Kay specifically designed the HISS system for hand injuries distal to the carpal bones. ${ }^{[3]}$ The MHISS, devised by Urso-Baiarda et al., ${ }^{[4]}$ is a similar scoring system which includes a wrist and forearm assessment. In the original, prospective study by Urso-Baiarda et al., ${ }^{[4]} \mathrm{a}$ postal questionnaire or semi-structured telephone interview was used; the mean MHISS of the responders ( $n=84$ ) was 74 (range: 2-7I2). Sixteen responders (19\%) who did not return to their previous employment exhibited a mean MHISS of 15I.5. According to Urso-Baiarda et al., ${ }^{[4]}$ MHISS was the only predictor of return to work among the factors examined; responders with more severe injuries were less likely to return to work. For example, only $60 \%$ of those with major hand injuries (as defined by the MHISS) returned to work. In the present study of 94 patients, the mean MHISS was 125.23 (range: 5-880). Seven patients (7.4\%) did not return to their previous employment because they had a mean MHISS of 738 (range: $420-880$ ). Notably, $72 \%$ of the patients with major injuries, as defined by the MHISS, returned to work. In the present study, the mean injury score was much higher than that reported by Urso-Baiarda et al., ${ }^{[4]}$ which may be because there were more patients with major injuries in our study than in the prior study. Moreover, patients with different types of injuries might have been assessed in the two studies.

Several studies have revealed a positive correlation between the severity of the injury and the length of time to return to work. $[2,3,8,14,17,18]$ Similarly, we found a statistically significant correlation between the MHISS and time to return to work. However, many variables besides the injury itself may influence the time to return to work; these include physical, psychosocial, demographic and employment factors. ${ }^{[8,18-21]}$ Some researchers reported that the time to return to work could be influenced by age and sex. ${ }^{[22]}$ However, in our study, no significant relationship was found between age and the following variables: MHISS, UEDR, TBDR and time to return to work.

Trybus et al. ${ }^{[23]}$ have declared that the economic consequences of serious hand injuries are considerable, and approximately $5 \%$ of the afflicted have to change their occupation, whereas approximately $5 \%$ have to retire. Furthermore, they have reported a clear connection between permanent functional restriction and return to employment. ${ }^{[23]}$ In another study comprising 79 patients aiming direct and indirect costs and factors influencing these costs in patients presenting following traumatic hand injuries, the average time to return to work was II4.7 days. In the same study, while $71 \%$ of the patients returned to their previous job, $29 \%$ of them had to leave or change their job. ${ }^{[24]}$ In our study, the average time to return to work was 138.7 days, and $86.2 \%$ of the patients returned to their previous jobs, whereas $13.8 \%$ of the patients had to leave or change their job. 
The literature has a minimal emphasis on the correlation between disability rating and time to return to work. Notably, a disability rating may indicate injured patients' limitations and permanent abilities; thus, it is a key factor in the return to full employment. Several studies have reported that the initial anatomical severity of a hand injury could influence final hand function as well as disability after maximal recovery. ${ }^{[5-7,19]}$ Mink van der Molen et al. ${ }^{[2]}$ proposed using HISS as a guide to predict outcomes, subsequent impairment and disability. They evaluated correlations between the HISS and measures of impairment and disability six months after a hand injury, as measured using the AMA guidelines. ${ }^{[25]}$ The mean HISS score was 64; the mean AMA impairment for the hand was $17 \%$, for the upper extremity was $25 \%$ and for the total body was 15\%. Notably, those investigators reported a statistically significant positive correlation between HISS and residual impairment. ${ }^{[2]}$

To our knowledge, this study is the first investigation in Turkey on the relationship between initial anatomical severity of hand, wrist and forearm injuries, as measured by the MHISS, and the disability rating, as evaluated by the 'Regulation on Disability Criteria, Classification and Health Board Reports to be Given to Disabled People'. This regulation comprises the system currently used in Turkey to measure disability after musculoskeletal injuries and comprises a detailed, reproducible system. We found statistically significant correlations between MHISS and UEDR, TBDR and time to return to work and UEDR, TBDR. Notably, higher MHISS scores were associated with higher disability ratings, as well as less favourable functional results. In addition, the length of time to return to work increased with higher disability ratings.

A few studies in Turkey showed that the most common cause of hand injuries was occupational accidents; these injuries primarily occurred in men. In our study, the male-to-female ratio was approximately $3: I$; according to the MHISS grade, minor injuries were more common in women, while major injuries were more common in men. This is likely a result of the increased presence of men in industrial work. ${ }^{[26,27]}$ Another study by Sozbilen et al. ${ }^{[12]}$ assessed the characteristics of hand and forearm injuries caused by angle grinders and determined risk factors for this type of injury; the investigators found that the mean overall MHISS score was 74 (2-330), and that angle grinder injuries were often severe, difficult to treat and caused a high rate of resulting disability. Another study by Çakır et al. ${ }^{[28]}$ investigated the relationships between injury severity and the following factors: return to work, impairment, activity and participation levels among patients who had experienced hand and forearm injuries. The investigators found that return to work, return to activity and participation were delayed with increasing MHISS.

In our study, the mean MHISS was higher than in previous studies, possibly because we included combined severe crush type injuries, including the hand, wrist and forearm in seven patients in our study. Thus, more complex injuries were associated with increased MHISS. Indeed, the score was quite high in these patients (mean MHISS 738, range: 420-880), so the mean overall MHISS was higher.

Previous studies have reported that work accidents result in a longer time to return to work than those occurring elsewhere. The authors suggested that these results could be because work accidents predominantly occur in workers who use hand tools (e.g., carpenters, mechanics, fitters), warranting the need for advanced manual skills for these individuals to continue to their job. ${ }^{[1,5,10,24,29]}$ More than half of the patients $(52.1 \%)$ included in our study had work accident injuries and their pre-injury jobs (e.g., construction workers, textile workers, mechanic/repair workers) required high-level hand skills. Patients with bilateral injuries or injuries to the other parts of the body were excluded from the study because this would negate (bias) the time to return to work. Furthermore, the claim of the workers' compensation and litigations may extend the time to return to work. ${ }^{[24,29-31]}$ In our study, seven patients who did not return to work had the right to claim disability benefits according to the Social Insurances and General Health Insurance Law in Turkey. Possibly, these patients experienced benefits from not resuming their work

Injuries to the hand and wrist account for approximately $20 \%$ of the visits to emergency departments. ${ }^{[33-35]}$ Although these injuries vary according to the developmental characteristics of the countries and/or regions and the severity of the injuries, they occur mostly after work accidents, and young active men are affected. ${ }^{[13,23,35-37]}$ In our study, young adult men were most commonly affected. This finding is consistent with the literature. Occupational injuries mostly occurred in the construction sector in the studies by Celik et al. ${ }^{[37]}$ and Garg et al., ${ }^{[38]}$ with rates of $28.7 \%$ and $30 \%$, respectively. Ozkan et al. ${ }^{[39]}$ reported that the majority of the victims of occupational accidents worked in the manufacturing and construction sectors (60\% and $24 \%$, respectively). Bursa is one of the outstanding industrialized cities of Turkey, particularly in the textile, automotive and construction sectors. In our study, $52.1 \%$ of the patients were injured due to occupational accidents, and the most common injuries occurred among textile workers (18.1\%), mechanic/repair workers (13.8\%) and construction workers (10.6\%). These sectoral variations are probably due to regional differences.

Our study had several limitations. First, the method involved a retrospective design. Second, only one surgeon graded all MHISS scores and disability ratings, so the study exhibits internal inconsistency. Further research is needed on the reliability and validity of disability rating measurements and of the MHISS. Third, there was no standard postoperative regular rehabilitation programme for patients included in this study. Fourth, workers' compensation cases were not well 
documented in our study. There may be a difference between recovery time and return to work after hand injury. ${ }^{[5,13]}$ This difference may be because the patient working in a job that does not require dexterity returns to work early without complete recovery, whereas the patient working in a job that requires dexterity returns to work only after recovery occurs. Another disadvantage of our study was that factors, such as recovery time, length of hospital stay and the number of re-operations required for recovery, were not included in this study because the main objective of our study was to investigate the relationship between post-injury severity score and return to work.

\section{Conclusion}

Our results associated higher MHISS scores with increased disability ratings and longer time to return to work. Notably, as the initial injury severity increased, greater disability remained and the time to return to work increased. Predicting prognosis by determining the injury severity in the initial evaluation of patients may be important in predicting a patient's future permanent disability level; this can contribute to maintaining patient expectations at a reasonable level, thereby aiding in psychosocial support. This can also be important for employers who need to plan for the patient's return to work, as well as to identify patients who cannot return to their prior roles. Further studies with a larger sample are recommended to verify the validity of the findings and to complete missing aspects.

Ethics Committee Approval: This retrospective study was approved by the Clinical Research Ethics Committee of the Bursa Uludağ University Faculty of Medicine (Approval no: 2019-2/9).

Peer-review: Internally peer-reviewed.

Authorship Contributions: Concept: S.Ç., A.C., T.K.; Design: S.Ç., K.Y., E.E., T.K.; Supervision: S.Ç., A.C., T.K.; Fundings: S.Ç., A.C., K.Y., E.E., T.K.; Materials: S.Ç., A.C., T.K.; Data: S.Ç., A.C., K.Y., E.E.; Analysis: S.Ç., A.C., K.Y., E.E., T.K.; Literature search: S.Ç., A.C., K.Y., E.E.; Writing: S.Ç., A.C., K.Y., E.E.; Critical revision: S.Ç., AC, T.K.

Conflict of Interest: None declared.

Financial Disclosure: The authors declared that this study has received no financial support.

\section{REFERENCES}

1. O'Sullivan ME, Colville J. The economic impact of hand injuries. J Hand Surg Br 1993;18:395-8. [CrossRef]

2. Mink van der Molen AB, Ettema AM, Hovius SE. Outcome of hand trauma: the hand injury severity scoring system (HISS) and subsequent impairment and disability. J Hand Surg Br 2003;28:295-9. [CrossRef]

3. Campbell DA, Kay SP. The Hand Injury Severity Scoring System. J Hand Surg Br 1996;21:295-8. [CrossRef]

4. Urso-Baiarda F, Lyons RA, Laing JH, Brophy S, Wareham K, Camp D. A prospective evaluation of the Modified Hand Injury Severity Score in predicting return to work. Int J Surg 2008;6:45-50. [CrossRef]

5. van der Molen AB, Matloub HS, Dzwierzynski W, Sanger JR. The hand injury severity scoring system and workers' compensation cases in Wisconsin, USA. J Hand Surg Br 1999;24:184-6. [CrossRef]

6. Saxena P, Cutler L, Feldberg L. Assessment of the severity of hand injuries using "hand injury severity score", and its correlation with the functional outcome. Injury 2004;35:511-6. [CrossRef]

7. Lee CL, Wu MY, Chang JH, Chiu HY, Chiang CH, Huang MH, et al. Prediction of hand function after occupational hand injury by evaluation of initial anatomical severity. Disabil Rehabil 2008;30:848-54. [CrossRef]

8. Lee YY, Chang JH, Shieh SJ, Lee YC, Kuo LC, Lee YL. Association between the initial anatomical severity and opportunity of return to work in occupational hand injured patients. J Trauma 2010;69:E88-93. [CrossRef]

9. Lin DC, Chang JH, Shieh SJ, Tsai FH, Lee YL. Prediction of hand strength by hand injury severity scoring system in hand injured patients. Disabil Rehabil 2012;34:423-8. [CrossRef]

10. Rosberg HE, Carlsson KS, Cederlund RI, Ramel E, Dahlin LB. Costs and outcome for serious hand and arm injuries during the first year after trauma - a prospective study. BMC Public Health 2013;13:501. [CrossRef]

11. Eriksson M, Karlsson J, Carlsson KS, Dahlin LB, Rosberg HE. Economic consequences of accidents to hands and forearms by log splitters and circular saws: cost of illness study. J Plast Surg Hand Surg 2011;45:28-34. [CrossRef]

12. Sozbilen MC, Dastan AE, Gunay H, Kucuk L. A prospective study of angle grinder injuries in the hands and forearms during a one-year period. Hand Surg Rehabil 2018;37:300-4. [CrossRef]

13. Altan L, Akin S, Bingöl U, Ozbek S, Yurtkuran M. The prognostic value of the Hand Injury Severity Score in industrial hand injuries. Ulus Travma Acil Cerrahi Derg 2004;10:97-101.

14. Matsuzaki $H$, Narisawa $H$, Miwa $H$, Toishi S. Predicting functional recovery and return to work after mutilating hand injuries: usefulness of Campbell's Hand Injury Severity Score. J Hand Surg Am 2009;34:8805. [CrossRef]

15. Regulation on Disability Criteria, Classification and Health Board Reports to be Given to Disabled People. Available from: http://www. resmigazete.gov.tr/eskiler/2013/03/20130330-4.htm. March 30, 2013.

16. Baker SP, O'Neill B, Haddon W Jr, Long WB. The injury severity score: a method for describing patients with multiple injuries and evaluating emergency care. J Trauma 1974;14:187-96. [CrossRef]

17. Wong JY. Time off work in hand injury patients. J Hand Surg Am 2008;33:718-25. [CrossRef]

18. Chang JH, Wu M, Lee CL, Guo YL, Chiu HY. Correlation of return to work outcomes and hand impairment measures among workers with traumatic hand injury. J Occup Rehabil 2011;21:9-16. [CrossRef]

19. Opsteegh L, Reinders-Messelink HA, Schollier D, Groothoff JW, Postema K, Dijkstra PU, et al. Determinants of return to work in patients with hand disorders and hand injuries. J Occup Rehabil 2009;19:245-55.

20. Rusch MD, Dzwierzynski WW, Sanger JR, Pruit NT, Siewert AD. Return to work outcomes after work-related hand trauma: the role of causal attributions. J Hand Surg Am 2003;28:673-7. [CrossRef]

21. Ramel E, Rosberg HE, Dahlin LB, Cederlund RI. Return to work after a serious hand injury. Work 2013;44:459-69. [CrossRef]

22. Meiners PM, Coert JH, Robinson PH, Meek MF. Impairment and employment issues after nerve repair in the hand and forearm. Disabil Rehabil 2005;27:617-23. [CrossRef]

23. Trybus M, Lorkowski J, Brongel L, Hladki W. Causes and consequences of hand injuries. Am J Surg 2006;192:52-7. [CrossRef]

24. Şahin F, Akca H, Akkaya N, Zincir ÖD, Işik A. Cost analysis and related factors in patients with traumatic hand injury.J Hand Surg Eur Vol 
2013;38:673-9. [CrossRef]

25. Doege TC. AMA Guides to the Evaluation of Permanent Impairment. 4th edition. Chicago, IL: American Medical Association; 1993.

26. Ozçelik B, Ertürer E, Mersa B, Purisa H, Sezer I, Tunçer S, et al. An alternative classification of occupational hand injuries based on etiologic mechanisms: the ECOHI classification. Ulus Travma Acil Cerrahi Derg 2012;18:49-54. [CrossRef]

27. Davas Aksan A, Durusoy R, Ada S, Kayalar M, Aksu F, Bal E. Epidemiology of injuries treated at a hand and microsurgery hospital. Acta Orthop Traumatol Turc 2010;44:352-60. [CrossRef]

28. Çakır N, Özcan RH, Kitiş A, Büker N. Investigation of the relationship between severity of injury, return to work, impairment, and activity participation in hand and forearm injuries. Ulus Travma Acil Cerrahi Derg 2014;20:120-6. [CrossRef]

29. Johns AM. Time off work after hand injury. Injury 1981;12:417-24.

30. Woodyard JE. Injury, compensation claims and prognosis: part I. J Soc Occup Med 1980;30:2-5. [CrossRef]

31. Woodyard JE. Injury, compensation claims and prognosis: Part II. J Soc Occup Med 1980;30:57-60. [CrossRef]

32. de Putter CE, Selles RW, Polinder S, Panneman MJ, Hovius SE, van
Beeck EF. Economic impact of hand and wrist injuries: health-care costs and productivity costs in a population-based study. J Bone Joint Surg Am 2012;94:e56. [CrossRef]

33. Larsen CF, Mulder S, Johansen AM, Stam C. The epidemiology of hand injuries in The Netherlands and Denmark. Eur J Epidemiol 2004;19:323-7. [CrossRef]

34. Angermann $\mathrm{P}$, Lohmann M. Injuries to the hand and wrist. A study of 50,272 injuries. J Hand Surg Br 1993;18:642-4. [CrossRef]

35. Sorock GS, Lombardi DA, Hauser RB, Eisen EA, Herrick RF, Mittleman MA. Acute traumatic occupational hand injuries: type, location, and severity. J Occup Environ Med 2002;44:345-51. [CrossRef]

36. Unlü RE, Abacı Ünlü E, Orbay H, Sensöz O, Ortak T. Crush injuries of the hand. Ulus Travma Acil Cerrahi Derg 2005;11:324-8.

37. Celik K, Yilmaz F, Kavalci C, Ozlem M, Demir A, Durdu T, et al. Occupational injury patterns of Turkey. World J Emerg Surg 2013;8:57. [CrossRef]

38. Garg R, Cheung JP, Fung BK, Ip WY. Epidemiology of occupational hand injury in Hong Kong. Hong Kong Med J 2012;18:131-6.

39. Ozkan S, Kiliç S, Durukan P, Akdur O, Vardar A, Geyik S, et al. Occupational injuries admitted to the Emergency Department. Ulus Travma Acil Cerrahi Derg 2010;16:241-7.

\section{ORIJIINAL ÇALIŞMA - ÖZET}

\section{Akut el, el bileği ya da ön kol yaralanmalarında yaralanmanın ciddiyeti ile özürlülük oranları ve işe geri dönüş zamanı arasındaki ilişki \\ Dr. Sercan Çapkın, Dr. Ali Cavit, Dr. Kutay Yılmaz, Dr. Eralp Erdoğan, Dr. Tufan Kaleli}

Uludağ Üniversitesi Tıp Fakültesi, Ortopedi ve Travmatoloji Anabilim Dalı, El Cerrahisi Bilim Dalı, Bursa

AMAÇ: Modifiye El Yaralanması Ciddiyet Skoru (MEYCS) ile değerlendirilen el, el bileği ve ön kol yaralanmalarının başlangıçtaki anatomik şiddeti ile yaralanma sonrası özürlülük oranları ve işe geri dönüş zamanı arasındaki ilişkiyi araştırmaktır.

GEREÇ VE YÖNTEM: Çalışmaya akut el, el bileği ve önkol yaralanması nedeniyle ameliyat edilen 94 hasta alındı. Yaralanmanın şiddeti MEYCS ile belirlendi. Yaralanmadan 6 ay sonra hastaların özürlülük oranları ‘Özürlülük Ölçütü, Sınıflandırması ve Özürlülere Verilecek Sağlık Kurulu Raporları Hakkında Yönetmelik’e göre hesaplandı. İşe geri dönüş süresi, yaralanma ile hastanın işe geri dönüşü arasındaki sürenin (gün) uzunluğu olarak tanımlandı. MEYCS ile özürlülük oranları ve işe geri dönüş zamanı arasındaki ilişki Sperman korelasyon analizi ile araştırıldı.

BULGULAR: Ortalama MEYCS; I 25.23 (5-880), üst ekstremite özürlülük oranı (ÜEÖO); I 7.64 \pm 22.6 (dağılım: 0-94) ve total vücut özürlülük oranı (TVÖO); $10.57 \pm 13.45$ (dağılım: 0-56) olarak bulundu. Çalışmaya dahil edilen 87 (92.6\%) hasta eski işine geri döndü. Ortalama işe geri dönüş zamanı; 138.69 (dağılım: 35-365 gün) olarak bulundu. MEYCS ile ÜEÖO ve TVÖO arasında, işe geri dönüş zamanı ile ÜEÖO ve TVÖO arasında istatiksel olarak anlamlı bir korelasyon bulundu $(p<0.00 \mathrm{I})$.

TARTIŞMA: Sonuç olarak, yaralanmanın başlangıçtaki şiddeti arttıkça hastaların özürlülük oranları ve işe geri dönüş zamanları artmaktadır. Hastaların ilk değerlendirmesinde yaralanmanın ciddiyetini saptayarak prognoz hakkında ön görüye sahip olmak hastaların gelecekteki kalıcı sakatlık seviyesini tahmin etmede ve böylelikle hasta beklentilerinin makul düzeyde tutulması sağlanarak psikososyal destek açısından önemli olabilir.

Anahtar sözcükler: İşe geri dönüş zamanı; MEYCS; özürlülük oranı; yaralanma şiddeti.

Ulus Travma Acil Cerrahi Derg 2020;26(3):453-46I doi: 10.14744/tjtes.2019.40524 